\title{
The Function Analysis of Village Regulations and Agreements in Modern Rural Governance
}

\author{
Teng $\mathrm{Hu}$ \\ School of Political Science and Public Administration \\ University of Electronic Science and Technology of China \\ Chengdu, China 611731
}

\begin{abstract}
Nearly forty years after the reform and opening up, China's urbanization process has made tremendous progress. At the same time, nearly 600 million people still live in rural areas, which make China's rural governance still a long-term task. The phenomenon of dualization of urban and rural legal system has increased the difficulty of determining the basic norms in modern rural governance. As a grassroots behavioral norm with a long history and widespread in rural areas, the village regulations and agreements are not negligible in modern rural governance. Therefore, this paper attempts to find out the obstacles or problems in the reality through the analysis of the function of the village regulations and agreements in the modern rural governance, and proposes a solution path, in order to truly play the benign role of the village regulations and agreements.
\end{abstract}

Keywords-village regulations and agreements; modern; rural governance; function analysis

\section{INTRODUCTION}

Fei Xiaotong believes in his book "Local China": "From the grassroots level, Chinese society is local" [1]. Although the book was written at the end of the 1940s in the last century, and the transformation of the new China has made the characteristics of this local society greatly weakened, the true nature of the rural areas in China today can be preserved. Under this circumstance, the village regulations and agreements as the norms of grassroots self-government in the local society have become the objects that we should pay attention to and study today. In the history, the village regulations and agreements are more embodied in the internal governance of the village. It is a rural internal governance norm formulated and promoted under the leadership of the village gentry and the family elite. It has the characteristics of locality, originality and inheritance which can make up for the shortcomings of the national law on rural governance and achieve orderly governance of rural society. Today, in the context of comprehensively advancing the rule of law, the modern village regulations and agreements are still the villagelevel governance norms that are only effective in the villages, and their contents have quietly changed as the national laws continue to penetrate the countryside. As far as today is concerned, the village regulations and agreements are not only the public contract of the residents in the village, but also the local governance norms within the national legal and policy framework. Its implementation effectiveness is closely related to the common conviction and execution of the villagers, is closely related to the process of integrating state law into the countryside.

\section{FunCtional Positioning ANALYSIS OF VILLAGE REGULATIONS AND AGREEMENTS}

\section{A. Village Regulations and Agreements Are Public Contracts in the Governance of Rural Legalization}

In nature, the village regulations and agreements have the nature of a public contract. From the perspective of "public law", the village regulations and agreements are jointly formulated by all villagers on the basis of extensive participation of the villagers. It is an important contractual norm for villagers to transfer their own rights through agreements, forming public power, and realizing villagers' autonomy. From the perspective of "private law", the village regulations and agreements are based on the normative documents adopted by the voting (discussed by the villagers' meeting is an indispensable procedure), which is a public system confirmed by the common agreement among all villagers in a community. The villagers' compliance with the village regulations and agreements is also a fulfillment of contractual obligations

In terms of content, the village regulations and agreements are based on the rural conditions, the village situation, and the people's sentiment, closely combined with the actual situation of the locality, based on solving the problems existing in the village, the measures formulated are concrete and practical. And through detailed terms, it is accurate and clear to tell the villagers what to do, what not to do, and easy to be understood and accepted by the masses.

In terms of implementation, the village regulations and agreements are based on the rural self-management led by the villagers' self-governing institutions. Despite the lack of state power guarantees, the village regulations and agreements have the nature of villagers' contracts and are generated by mutual agreement, formulated by people's consent, the villagers are more binding, and they can basically ensure their effective implementation through mutual supervision and selfmanagement of the villagers. 


\section{B. Village Regulations and Agreements Are the Local Governance Rules for Maintaining Grassroots Stability}

The village regulations and agreements have been established in ancient times, and its origin can be traced back to the Lvshi local rules of Lantian County, Jingzhao, the Song Dynasty. Qin Hui believes that since the middle of the Sui Dynasty to the Qing Dynasty, the nation power stopped in the state and county, and the nostalgic class dominated rural social governance. [2] In various periods in history, the village regulations and agreements were controlled by the nostalgia under the default of the rulers, promulgated by the rulers in the form of national laws, and their governance functions were never weakened. After the founding of the People's Republic of China, the state established the township people's government in the countryside, breaking the practice of "national power does not go down the county" in the traditional society, and replaced the rural governance function of the nostalgic forces in the form of state power. Especially in "the Great Cultural Revolution" and "Inverted Confucianism" movements, the village regulations and agreements were abandoned because they were regarded as decaying and backward traditional culture. After the reform and opening-up, the rural household contracted management system was gradually established, the government's intervention in the countryside was gradually reduced, and farmers began to be freed from the government's strong control. In 1983, the township government system was formally formed, and the role of village regulations and agreements in village selfgovernment was fully exerted. More and more villages formulated or revised, became the main local governance norms for self-management in rural grassroots. In the subsequent development, especially in the context of governing the country according to law, as a "quasi-law" between national laws and ethics, village regulations and agreements are no longer just pure moral norms, but gradually become the place version of national law. Realizing the orderly governance of modern villages urgently needs to perfect such "behavioral norms based on beliefs, customs, social public opinion, and the nature of contractual jurisprudence", thereby effectively promoting the villagers' self-government process and realizing the "management democracy" of the new socialist countryside. [3]

\section{Village Regulations and Agreements Are the Norms of the Basic Behavior of Residents in Administrative Villages}

The political basis of the village regulations and agreements is a villager autonomy system based on consultations. [4]In the rural grassroots governance, the village regulations and agreements have played an active role in resolving conflicts at the grass-roots level, maintaining the order in production and management in rural areas, promoting the construction of spiritual civilization, changing prevailing habits and customs, and stabilizing the rural order. The villagers' compliance with the village regulations and agreements has effectively promoted rural harmony. Due to the low level of peasants' educational culture, they have little knowledge of professional laws and regulations, and they can only accumulate a little legal knowledge from their life experience. The village regulations and agreements, according to the different village conditions and public opinion of each village, under the leadership of the village committee, are written by the local villagers with higher cultural level, which are closely combined with the rural actual conditions and respect the local rural traditional customs. It is close to the life of peasants with a strong pertinence, popular and easy to understand. It is used to manage village affairs, regulate villagers' behaviors, and maintain rural order, which is more operational and effective.

\section{ANALYSIS OF THE MAIN OBSTACLES TO THE}

\section{REALIZATION OF THE FUNCTION OF VILLAGE REGULATIONS AND AGREEMENTS IN MODERN SOCIETY}

The traditional Chinese countryside is relatively closed, and only maintains a low sustained and low-speed development. In this context, the village regulations and agreements formulated or formed according to customary rules or villagers' production and life are enough to maintain the basic order of the village. However, under the leadership of the country, modern rural areas have rapidly advanced the process of urbanization. With rapid economic and social development and accelerated transformation of rural society, new contradictions have emerged. Plus the influence of the weak legal awareness of the villagers, the imperfect formulation procedures of village regulations and agreements, the inadequacy of the relevant departments and other factors, the village regulations and agreements in some places still have many problems and have not played the expected role. The village regulations and agreements are far from the requirements of rural governance modernization, and the governance function has not been fully utilized.

\section{A. The Individual Provisions of the Village Regulations and Agreements Are in Conflict with the Mainstream National Governance Rules}

The village regulations and agreements stipulate indiscriminate economic penalties, which are in conflict with national laws. Article 27 of the Organic Law of Villagers' Committees sets boundaries for village regulations and agreements that do not contradict the constitution, laws, regulations and national policies, and defines red lines that do not violate the personal rights, democratic rights and legal property rights of the villagers. However, in practice, the village regulations and agreements still have a lot of traditional feudal rule of man, which imposed indiscriminate punishment in the name of autonomy. It is understood that in recent years, the government has standardized the basic forms of village regulations and agreements, and many local government judicial offices have formulated a unified model. However, the phenomenon of unreasonable fines in the village regulations and agreements still exists, and as long as the number of fines is not too large, it will generally be acquiesced by the township government. In fact, in the rural areas of remote mountainous areas, there are still individual villages where the village regulations and agreements are in a "native" state. There are 13 village rules in a natural village in a mountainous area, and each article involves fines. Only Article 10 does not have a clear number of fines, and its provisions are stated as "no damage to water conservancy construction, and offenders shall be punished according to their circumstances". According to 
the "Administrative Punishment Law", as an autonomous norm for village regulations and agreements, it is obvious that there is no right to set administrative penalties; according to the "Administrative Coercion Law", villagers' committees as mass autonomous organizations are not eligible for fines. It can be seen that the setting of these punitive clauses clearly exceeds the national laws and is also a violation of the property rights of the villagers under the Constitution. In addition, some villages have established other punitive measures in their village regulations and agreements, such as doing volunteer work, restricting contracting, reducing dividends, and not applying for the basic living allowance and health insurance, etc. Although the village regulations and agreements are formally formulated or recognized by the villagers, due to the low legal level and weak sense of rights of the villagers, they do not necessarily know that their legitimate rights and interests have been damaged, and they have defaulted to the deprivation of rights. This has damaged the justice of society and undermined the unity of the legal system.

\section{B. The Village Regulations and Agreements Have Hampered the Production and Management, Which Is Contrary to National Policies}

The ownership of rural land belongs to the collective of the village or group. However, after the implementation of the household contract, the ownership, contracting and management rights of the land are separated from each other, and the country also encourages land circulation. In some localities, the village regulations stipulate that the contractor may not sublet the land or transfer the contract, and the village committee or the village group may withdraw the land use right at any time. There is such a stipulation in the village regulations and agreements of a village: it is forbidden to exchange land privately, otherwise the land will be repossessed and a fine of 20 yuan will be imposed, and the wasteland will be charged 40 yuan per acre per quarter. In fact, while enjoying the right to contracted management, farmers also enjoy the right of transfer according to law. Therefore, the village regulations and agreements cannot break the provisions of the law to limit the rights enjoyed by farmers according to law. However, some villages are engaged in agricultural industrialization under the guidance of the township government. In order to fulfill the "guidance" goal issued by the government, the village committee temporarily formulated village regulations to require villagers to plant economic crops such as medicinal materials and rapeseed. Violators will be unable to enjoy or be restricted from enjoying the National Benefits Policy. This restriction on land subcontracting and the regulation of economic indicators clearly contradicted the national policy and violated the farmers' autonomy in production and operation. In addition, some places have reserved certain fees and charges in the village regulations and agreements, such as sharing the payment and work in the construction of rural roads and the environmental pollution charges in rural cleaning projects.

\section{In the Process of Formulation, the Village Regulations and Agreements Lack the Guarantee of Villagers' Right of Autonomy}

Regarding the provisions on the formulation of the main body of the village regulations and agreements, the Organic Law on the Village Committee only provides that the village meeting can formulate or amend the village rules and regulations in Article 27, and in Article 25, for matters authorized by the villagers' meeting, it gives the villagers' representative meeting the right to discuss and decide, but does not clearly stipulate the procedures for the formulation of the village regulations and agreements. As far as the original intention of legislation is concerned, the village regulations and agreements concerning the basic behavioral norms of all villagers in the village should be formulated by the villagers through the meeting, but not by the villagers' representative meeting. In practice, the formulation of many village regulations and agreements is very simple. Some of them are modified from the original village regulations, and some just copy the ones of neighboring villages. They neither fully solicit public opinions, nor hold a village meeting to study and discuss. When the articles were written, the village cadres would find an opportunity to announce if they felt the articles are ok. It is precisely because the procedures are not standardized, the legal literacy of the formulators is not high, and they work behind closed doors, so that the village regulations and agreements are incomplete and inefficient in action. Due to the formulation of village regulations and agreements lacks the procedural regulations, and it is basically determined by the village cadres, lacking village participation and the protection of the villagers' self-government rights, the villagers who are the subject of restraint certainly do not agree with such village regulations and agreements, of which the rural governance function will naturally be weakened.

\section{In the Process of Implementation, Village Regulations and Agreements Are Often Resisted and Lack of Execution}

There are many barriers in the implementation process of village regulations and agreements, and the effect is not obvious. The "penalty offer" is still one of the basic components of the village regulations and agreements. [5] In the rural areas, the clan forces in some places have signs of recovery. They can control the village-level decision-making by virtue of the "safety-in-numbers", and even control voting and elections. Village regulations and agreements that have not been developed by the villagers are likely to be resisted. Even if they are established through legal procedures, they may encounter resistance as long as it affects the vital interests of villagers within a certain group. In the process of urbanization in rural areas, in order to promote the overall planning of administrative villages, some village cadres abused their powers to formulate village regulations and agreements, then used some villagers' representatives who supported the decision of the village committee to formally vote on them, which alienated the village regulations and agreements into a "protective umbrella" for village cadres to make illegal decisions. This not only damages the property rights of the villagers, but also affects the implementation of national laws and regulations in the vast rural areas and undermines the 
socialist rule of law, and ultimately hindered the implementation of the village regulations and agreements.

\section{The REALIZATION PATH OF the ViLlage REGULATIONS AND AGREEMENTS IN MODERN RURAL GOVERNANCE}

\section{A. Improving the Basic Quality of the Main Body of the Village Regulations and Agreements}

It is a difficult process from the rule of man to the rule of law. The traditional feudal patriarchal management lacks the elements of democracy, which makes it easy for some village cadres to engage in "What one says goes" by convention. The existence of some old policies and old regulations, the existence of old village regulations and agreements in a few villages, and the occlusion of the villages make it easy for village regulations and agreements to follow traditional practices without thinking about new methods and contents. Although there have been many provisions that contradict national laws and policies, because the villagers' legal awareness is generally weak, and they do not know how the law is regulated and what rights the law gives themselves, these illegal provisions are passed and implemented. Therefore, in the process of formulating, it is necessary to select the group members who draft the village regulations and agreements, really bring in those who have high moral cultivation and knowledge, strong sense of responsibility, care for rural development, can hold justice, and can effectively think for the masses. The grass-roots government should strengthen guidance, increase the training of personnel drafting village regulations and agreements, and effectively enhance their democratic awareness and legal and policy levels, so that they truly become "speakers" of the interests of the masses.

\section{B. Strengthening the Guidance of Grassroots Governments on the Formulation of Village Regulations and Agreements}

The Organic Law of Villager Committees gives the grassroots government the power and responsibility to strengthen the guidance of the villages in formulating or revising the village regulations and agreements. The townships, ethnic townships and town governments should perform their duties effectively. Under the premise of respecting the implementation of the Constitution, laws and guarantee policies, they should give guidance to ensure that the villagelevel "regulations" are combined with the actual conditions of the village and comply with laws and policies. The grassroots government's guidance on the village regulations and agreements mainly has three aspects: the first aspect is the necessity of formulating the village regulations and agreements. For content that only involves the individual rights of individual villagers, it is generally not recommended to formulate village regulations and agreements. For the affair management involving only a certain villager group, it is generally not recommended to formulate village-level regulations, but the rules in the group can be formulated by the group under the guidance of the village committee; the second aspect is the procedure for the formulation of the village regulations and agreements. It is necessary to put forward clear procedural requirements, including announcements and mobilization, organization and convening of villagers' meetings or meetings of villagers' representatives, meeting agendas, voting methods, etc., giving opportunities to interested parties to express their interests[6]; third, in terms of the content to be stipulated by the village regulations and agreements, the fine guidance should be carried out, and for those that are difficult to implement, the consequences of implementation and the consequences of non-execution should be considered, and those that do not coincide with the national laws and policies should be resolutely eliminated, for that infringing upon the lawful rights and interests of rural areas must be strongly blocked. In the actual guidance, the grassroots government's punishment for the village regulations and agreements should not be generalized. In short, regulations that are not punishable are unlikely to be universally observed. While acquiescing to the village to make appropriate economic penalties, it is necessary to have a clear definition of its nature - punishment is not directly authorized by national laws, nor is it based on sanctions created by legislation, but "All villagers pass the authorization of village regulations and agreements" [7].

\section{Strengthening the Township Government's Filing Review of the Village Regulations and Agreements}

The Organic Law of Villager Committees establishes the regulations for reporting and filing village regulations and agreements to townships, ethnic townships, and town governments. At present, the township people's government generally exercises this power by the judicial department. Since the judicial personnel generally only have 2-3 people, they must perform the law-enforcement functions, mediate the contradictions and disputes, and complete the various social public security comprehensive management tasks assigned by the government leaders and the county-level judicial bureau. Therefore, they rarely have the time and energy to conduct a voluntary review of the village regulations and agreements. Since the review is not detailed, individual village regulations and agreements with illegal content have also been filed. Therefore, the construction of grassroots judicial offices should be strengthened, and personnel should be selected and equipped. If conditions permit, special personnel can be implemented to carry out standardized management and strict review of the filing work. In practice, the record review should pay attention to two aspects: on the one hand, it is necessary to review the legality of the village rules and regulations. In terms of basic procedure review, whether there is a procedure for soliciting opinions and collective discussion from villagers, whether the village regulations and agreements are reviewed by the village representative meeting or the village meeting, and whether the relevant materials for discussion and voting are archived. The village regulations and agreements for the lack of procedures should not be filed and sent back for reconsideration and re-voting. On the other hand, it is necessary to review the legality of the content of the village regulations and agreements. The village regulations and agreements are a normative document and cannot be used as the basis for administrative punishment. According to this principle, based on the actual situation of the village, it is possible to formulate some incentives with the main purpose 
of positive guidance, such as the establishment of excellent student rewards, the rewards for transforming social traditions and simple funerals, and the rewards for behaving righteously. Therefore, it plays a guiding role in clearing the right and wrong and promoting the new ethos.

\section{Accelerating the Connection Between Village Regulations and Agreements and National Laws}

National laws and policies are more value-oriented and bottom-line guardian for rural grassroots society. [8]In order to obtain new life in modern rural governance, village regulations and agreements must accelerate the modern transformation and accelerate the interaction and integration between village regulations and agreements and national laws and regulations [9].On the one hand, village regulations and agreements should be positioned to supplement national laws and policies. The fields involved should include the specification of the principled content of the law, and the local governance content with unique local characteristics outside the law and policy. The norms that are clearly defined in the law need not be described in detail, but they can be advocated as the general content of the village regulations and agreements. On the other hand, the formulation of village regulations and agreements should strictly follow democratic procedures and fully guarantee the autonomy of the peasant masses. It cannot be constructed only by the village party branch committee and village committees or a few village representatives. Only the village regulations and agreements that involve the extensive participation of the villagers and reflect the willingness of the majority of the villagers may be consciously observed.

\section{CONCLUSION}

In general, the village regulations and agreements are a normative document with the nature of civil contract and the nature of villagers' autonomy. It is an important carrier for the orderly governance of rural areas under the current villagegovernance and village governance system. It is different from national laws and policies, but it is also the localization norm of the country's formal system in rural areas. The village regulations and agreements can be interpreted and supplemented in a localized language to ensure that the country's formal system is fully implemented in rural areas, providing guarantees for the stability and harmony of the local society. If through the guidance and standard, we can make the village regulations and agreements conform to national laws and policies, make villagers' autonomy and state administrations connected. It is expected to play an important role in rural governance and realize villagers' autonomy in the original sense.

\section{REFERENCES}

[1] Fei Xiaotong. Local China [M]. Beijing: Beijing Publishing House, 2005. (in Chinese)

[2] Qin Hui. Ten Theories on Tradition: The System, Culture of Local Society and Their Transformation [M]. Shanghai: Fudan University Press, 2003. (in Chinese)

[3] XieQiuhong. The Perfect Path of Village Regulations and Agreements under the View of Rural Governance[J]. Probe, 2014(5): 149. (in Chinese)
[4] Jiang Zusong. The Balance Effect of Village Regulations and Agreements on Administering the Village by Law in Village SelfGovernment System[J]. Jiangnan Luntan, 2016(11): 30. (in Chinese)

[5] Zhou Jiaming, Liu Zuyun. Research on the Internal Mechanism of Village Regulations and Agreements - Based on the Analysis Framework of Factor-action Mechanism[J]. Issues in Agricultural Economy, 2014(4):23. (in Chinese)

[6] QiuYoudu. The soft law role of village regulations and agreements in rural governance [J]. Journal of Party College of Sichuan Provincial, 2015 (3): 78. (in Chinese)

[7] Chen Yongrong, Li Jianghong. On the Regulation of Economic Punishment Agreement in Village Regulations and Agreements [J]. Theory and Reform, 2015(5): 151. (in Chinese)

[8] Zhou Tietao. The Contemporary Form of Village Regulations and Agreements and Its Rural Governance Function[J].Journal of Hunan Agricultural University, 2017(1):51. (in Chinese)

[9] Zhu Yangang, Jiang Shicong. Reflections on the Reconstruction of the Village Regulations and Agreements System[J]. People's Tribune, 2016(30):115. (in Chinese) 